\title{
Attitude of Students with Disabilities to Tutorial Assistance at the University
}

\author{
Kokhan S. T. \\ Regional Center for Inclusive Education, \\ Transbaikal State University \\ RCIE TSU \\ Chita, Russiae-mail ispsmed@mail.ru
}

\author{
Ivanov S. A. \\ Transbaikal State University \\ TSU \\ Chita, Russia \\ e-mail mail@zabgu.ru
}

\author{
Starostina S. E. \\ Transbaikal State University \\ TSU \\ Chita, Russia \\ email: sestarost@mail.ru
}

\begin{abstract}
The article presents the results of students' opinions sociological research in the framework of the inclusive education process, adaptation and social rehabilitation of students with disabilities. The article shows that the most students have a positive attitude towards co-education with special students and the participation of a tutor in organizing assistance to such students in the learning process. The results of the research revealed a lack of technical training tools used by totally blind and deaf students for the full assimilation of information, and also the need for further teaching staff to understand the problems that arise when working with such students. This research proves the need for the development of tutorial assistance and an accurate definition of tutor duties.
\end{abstract}

Keywords-tutor; adaptation; student with disabilities; inclusive education; and research.

\section{INTRODUCTION}

The development of higher inclusive education (HIE) is focused on the creation of the measures to support and accompany students with different health pathologies. The basic principles of the state policy in the field of education are some serious problems, which are aimed at equality of the persons rights who have health problems, their successful training and that they receive the affordable and quality higher education, taking into account psychophysiological, intellectual and individual characteristics of the students with special educational needs [4].

In modern Russian education, teachers began to use innovative pedagogical practices. They include tutorial assistance $[2,9]$. Interest in tutoring, manifested due to the fact that the federal state educational standards involve the realization of individual educational programs for people with disabilities [3,11]. Currently, the inclusive education of the students with disabilities is building an individual educational trajectory, when there is a special social position in an adult tutor, who assist the people with disabilities and determine the individual educational route. The tutor is necessary for more rapid and complete adaptation of students with disabilities with deep health disorders to the living and learning conditions at the university, which change the psychophysiological state of the person.

\section{LITERATURE REVIEW}

Since the late 90s of the XX century, tutorial practice is gaining a broad focus in various regions of Russia, relying on the British historical model [1].

In their works the authors Baglieri S., Janice H. V. focus on inclusive practices and special education, which can be transformed using the perspective of studying a student's disability, in promoting social justice in the marginalization of a disabled person [10]. The transformation of tutoring in various forms, including university, local, volunteer and other forms and conditions of interaction, was shown in the works of foreign authors Burnish, K. Topping [12, 13].

On practical experience the team of authors proved the need for teachers to use the adaptive structure in order to conduct psychological and behavioral interventions for students with disabilities to get the best learning outcomes [14].

Guanglun Michael $\mathrm{Mu}$, Yang $\mathrm{Hu}$, Yan Wang believe that teachers can significantly affect the growth of students with disabilities confidence in the learning process [16].

S. M. Mines argues that the problems of accompanying people with disabilities are largely due to psychosocial factors related with isolation and stigmatization. They make common problems in the formation of people with developmental disabilities [15]. 
possibility of tutorial assistance at the university leads students to have difficulty choosing an answer.

According to $46 \%$ of students, a tutor is a mentor working individually with one or more students, $27 \%$ of respondents define a tutor as a coordinator between a student and the educational system and $27 \%$ - as an assistant, correcting the actions of students with disabilities in the learning process.

The results obtained by the respondents indicate a correct understanding of the tutor's activities to ensure the implementation of the ideas of a personality-oriented approach and the integration of learning.

As for determining the tutor's functions, $22 \%$ of respondents believe that the main function is to build an individual educational path, $19 \%$ - to teach students to plan their own activities, $36 \%$ - to reveal the full range of opportunities for self-realization, and $23 \%$ - found it difficult to answer this question.

Respondents consider the main qualities of a tutor are compassion, understanding of students with disabilities problems, sociability, responsibility, initiative, creativity of thinking. It should be noted that most respondents consider the main qualities of a tutor are the presence of organizational abilities, the ability to find contact with people, a positive attitude.

It is worth noting that $27 \%$ of the respondents have difficulties in the educational process due to the lack of the necessary technical equipment.

When asked about the availability and possibility of tutoring at the university, the following results were obtained: $49 \%$ of respondents answered negatively, $36 \%$ answered positively, $15 \%$ - refrained from answering.

$48 \%$ respondents consider that teachers help to solve the problems that arise in the process of learning at the university, $40 \%$ respondents argue that classmates help them. The results are presented in the Table I.

The main array method was chosen during the questionnaire survey, where the total body of students with disabilities was 68 respondents. Respondents were asked to answer the questionnaire, which included 21 questions. Statistical processing of the obtained materials was carried out on a PC, the confidence interval did not exceed $5 \%$.

The research is to develop guidelines for tutorial assistance of people with disabilities. The results will allow making adjustments to improve the quality of students with health problems education, to expand and deepen scientific and practical ideas about educational technologies and features of tutorial assistance.

\section{RESULTS}

Based on the data obtained, it was found that $36 \%$ of respondents need tutorial assistance, $45 \%$ of respondents do not need it, $19 \%$ of respondents found it difficult to answer. The category of students with deep health problems was included in the group who need tutorial assistance. It should be noted that the lack of students awareness about the
TABLE I.

\begin{tabular}{|l|c|}
\hline \multicolumn{2}{|c|}{ Who helps to solve problems arising in the process of studying at the } \\
university? \\
\hline \multicolumn{1}{|c|}{ Answer } & $48 \%$ \\
\hline Teachers & $40 \%$ \\
\hline Classmates & $12 \%$ \\
\hline Friends & \\
\hline
\end{tabular}

The opinions of the respondents to the question of whether you consider tutoring as a separate profession were divided almost equally. At the same time, according to the results of the survey, it was found that the majority of respondents $(67 \%)$ believe that special knowledge is needed to fulfill the role of tutor.

The majority of students, when answering the question of whether you think that tutorial assistance is an important factor in the quality of higher education, answered affirmatively. The results are presented in the Table II. 
TABLE II.

Do you think that tutorial assistance is an important factor in the quality of higher education?

\begin{tabular}{|l|c|}
\hline \multicolumn{2}{|c|}{ Answer } \\
\hline Yes & $71 \%$ \\
\hline No & $3 \%$ \\
\hline Difficult to answer & $26 \%$ \\
\hline
\end{tabular}

It should be noted that the survey is aimed at revealing the knowledge of students with disabilities about the job functions of the tutor and studying their opinions on the nature of the tutor's activities.

In addition, the survey showed how students with disabilities understand the concepts of "tutoring", "tutoring technology" and "tutor"; revealed the need for students in tutorial assistance; reflected the expectations of students in interaction with the tutor and the scope of cooperation with him.

Based on the foregoing, we can conclude that according to students with health problems, tutorial assistance is not sufficiently developed in Transbaikal State University. It affects the process of adaptation and the success of training at the university.

For comprehensive tutoring support it is necessary to introduce modern educational and rehabilitation technologies; to provide psychological, pedagogical and social support for students with disabilities, to ensure the availability of technical training in sufficient quantities

\section{CONCLUSION}

The research indicates the existence of a number of tasks for the teaching staff to develop tutoring at the university. This is the development of support and management systems for the development of an inclusive student; the formation of key competencies and the creation of a space for professional self-determination of students with special educational needs.

Tutoring as an educational technology includes many aspects of inclusive work at the university and beyond. A systematic study of practice-oriented educational technologies will give impetus to the development of systemic thinking, reflection, critical thinking, empathy, as well as the general social competence of the tutor. The results of the research allow us to conclude that the effective interaction of the tutor - teacher, teacher-student and tutorstudent allows to improve the quality of educational results of students with disabilities, will contribute to the implementation of teamwork technologies in the educational process, and will also make it possible to create an inclusive educational environment of the Transbaikal State University.

\section{References}

[1]. Belitskaya, E.V. Trends in the development of the tutoring system of education in modern education in England. News of Volgograd State Pedagogical University. 2012, 1, pp. 132-135

[2]. Belyaeva T.K., Nikishina O.A. Tutoring as a resource for improving the quality of education of foreign students at a university. Modern problems of science and education. 2015, 6, URL: https://www.science-education.ru/en/article/view?id=22754.

[3]. Erofeeva N.E., Melekesov G.A., Chikova I.V. Experience of implementing tutorial support for the educational process at a university Bulletin of the Orenburg State University. 2015, 7 (182), pp. 98-104

[4]. Ivanov S.A. Transbaikal State University is the university developing inclusive education. Rector of the university. 2018, 12, pp. $40-43$

[5]. Kokhan S.T., Simonova V.O. Help everyone as much as you can!: guidelines. Transbaikal State University: Chita: TSU. 2019, 44.

[6]. Kovaleva T.M. The formation a new tutor profession in the Russian education. Issues of education. No.2, pp.163-180

[7]. Kovaleva T. M. Forward to the process of individualization! Tutoring support. 2012, 1 (2), pp. 14-16.

[8]. Kohan S.T., Pateyuk A.V., Antonov V.L. The organization of inclusive education in higher education. Chita: TSU. 2017, 120.

[9]. Romanova E.A. The position of the tutor in the system of modern higher education. International Research Journal. 2017, 3 (58), pp. 53-55

[10]. Sun Xiaoping The concept of "tutoring" in the scientific and educational literature. Vocational education in Russia and abroad. 2016, 4 (24), pp. 120-129

[11]. Chelnokova E.A., Nabiev R.B. Tutoring activities of a teacher to ensure the successful adaptation of students at a university. Bulletin of the University of Minin. 2015, .3. URL: http: //vestnik.mininuniver.ru/reader/search/tyutorskaya-deyatelnostpedagoga-po-obespecheniyu-/

[12]. Baglieri S., Janice H. Knopf Normalizing Difference in Inclusive Teaching. Journal of Learning Disabilities (Q1, WoS). 2004, 6, pp. 525-529

[13]. Burnish, Fuch \& Fuch. Peer-assisted learning strategies: An evidence-based practice to promote reading achievement//Learning Disabilities Research \& Practice. 2005, 15(2), pp. 85-91

[14]. Diane P. Bryant, Brian R. Bryant, Deborah D. Smith /Teaching Students With Special Needs in Inclusive Classrooms. 2019, 504

[15]. Guanglun Michael Mu, Yang Hu, Yan Wang Building resilience of students with disabilities in China: The role of inclusive education teachers. Teaching and Teacher Education. 2017, vol. 67, pp.125134

[16]. Mines S. M. That feeling of not being seen as whole: holistic therapy and people with disabilities (rehabilitation). Degree: Ph.D. Institute: The Union for Experimenting Colleges and Universities. 1988.

[17]. Topping K. Peer-assisted learning: A practical guide for teachers. Neeuton, Mass.: Brookline Books. 2000. 